\title{
THE APPLICATION OF COMPUTER AIDED LEARNING TO LEARN BASIC CONCEPTS OF BRANCHING AND LOOPING ON LOGIC ALGORITHM
}

\author{
Endra Rahmawati, Sulis Janu Hartati \\ Major of Information System, STMIK STIKOM Surabaya, Indonesia
}

\begin{abstract}
This paper reviews how to create an application based on Computer Aided Learning (CAL), which is the use of computers to deliver instructional materials and involve students / learners are active. This CAL application consists of 5 multimedia modules. Module 1 contains the basic concepts of data processing. Module 2 discusses the concept of flowcharts. Module 3 contains the testing applications using a flowchart. Module 4 contains the concept of nested selection. While the tutorial module 5 contains the concept of arrays and study case practice. To support this, CAL application is made as attractive as possible, by combining multimedia files, such as image files, sound files, and video files. With the CAL is equipped with modules of algorithms, students are expected to take computer courses, especially in STMIK STIKOM Surabaya can improve learning outcomes at the course logic algorithms.
\end{abstract}

\section{KEYWORDS}

Computer Aided Learning, Branching and Looping Concept, Logic Algorithm

\section{INTRODUCTION}

One of the courses in computer education is Algorithms and Programming. Currently, the algorithm logic course is the main subject in a variety of educational programs. Majors in STMIK STIKOM Surabaya who have the majority of computers, having trouble teaching the basic concepts of programming. This is due to the low ability students at logic algorithm. Based on the data obtained, only $60 \%$ of new students in STMIK STIKOM Surabaya who obtain a minimum value of $\mathrm{B}$ for the course logic algorithms. As a result, more than $50 \%$ of them are not able to make the application program. To overcome these problems, there should be a medium for learning new subjects algorithm logic. The subjects selected for special handling because it is a course that provides the basic ability to understand application programming [2].

Based on several previous studies, it was found that the algorithm logic courses include subjects that are not easy for students [1][7][8]To overcome this, they are doing research on the creation of software as a learning tool. Nevertheless, the study does not show how the learning algorithm logic concepts correctly. The majority of existing work, immediately gave the theory, formulas, 
The International Journal of Multimedia \& Its Applications (IJMA) Vol.5, No.6, December 2013

and pictures flowchart that has become, not taught the steps by steps how making a flowchart, and without testing whether flowchart that has been created can be run correctly or not.

A lot of phenomena that occur in the field of engineering as well as three-dimensional dynamic movements that are difficult for conventional represented in print media, such as learning geometry [3]. However it can be anticipated that the visualization has a better capacity. Visualization is paramount to implement an educational institution that is distance learning and blended learning. Development of visualization algorithms can be observed at the student concerned, with the aim of changing the paradigm of learning, from teacher centered learning to student centered learning [9]. In addition, learners find it easier and more attractive for learning algorithms in the multimedia environment [11][12]. Therefore, multimedia is an element that can increase motivation or interest in understanding the material presented by the teacher [5][6][10].

The Purpose built applications of Computer Aided Learning (CAL) is for learners or students can be actively involved in the learning process. To support this, CAL application is made as attractive as possible, by combining multimedia files, such as image files, sound files, and video files, such as game activity for children[4]. The files are packaged as modules being used as concept learning algorithms, such as form filling data, creating flowcharts, and learn from video tutorials. With the CAL which equipped by modules such algorithms, it is expected that students taking computer courses, especially in STMIK STIKOM Surabaya can improve learning outcomes at the course logic algorithms.

\section{COMPUTER AIDED LEARNING}

Computer Aided Learning (CAL) is the application of computers as an integral part of the learning system for learning and teaching process. CAL is basically a form of multimedia technology (in this case a computer) to deliver lessons. Computer has a privilege, not shared by other learning media . An application can be referred to as CAL application if it consists least two of the three following characteristics :

a. Teaching / Tutorials

Delivery of materials in order to be learned by the user .

b. Problems for practice

Giving the exercises according to the material that is taught to the user to measure the ability of the user to control of material that has been taught .

c. Simulation

Simulating the appearance of the material that is taught to the user . Usually the material needed for the simulation, so the user can see the experiment without having to do it for real. Experiments with subjects that require costly, dangerous, or take a long time for simulation .

\section{CONCEPT OF LOGiC ALgORITHM}

The algorithm is a logic course which aims to provide the basis to develop programming skills. Therefore, the subject matter is focused on making the process automation logic, which is expressed in the form of a flowchart and pseudocode [2]. The second presentation of the 
The International Journal of Multimedia \& Its Applications (IJMA) Vol.5, No.6, December 2013

algorithms using high-level languages, which the languages that can be understood by humans. Some basic concepts (related to programming) The basic concepts will be learn by students in course of 1 to 5 weeks include :

a) Understanding of the variables, data types, constants, operators, and relationship mathematical logic.

b) To know a variety of process automation, including sequential, branching, looping, and a combination of all three.

c) Presentation of the algorithm using a flowchart.

d) Learning the concept of nested branching, and

e) Learning concepts $1 \mathrm{D}$ and $2 \mathrm{D}$ arrays.

In this research, these concepts are divided into 5 modules, among others :

1) Module 1 : Concept of Data Processing, in which there are definitions of variables, data types, constants, operators, and mathematical logic relationships (relationships). In addition, the module 1 is introduced of the process of sequential, branching, and looping .

2) Module 2 : Concept of Create a Flowchart, in which there are step by step how to create a flowchart, both in the process of sequential, branching, and looping .

3) Module 3 : Video Tutorials of Testing Flowchart use RAPTOR application. This application can be downloaded free at http://raptor.martincarlisle.com. Goal of use additional RAPTOR applications, so that the flowchart was created on module 2 can be tested directly using the raptor, if it run correctly based on algorithm or not .

4) Module 4 : Concept of Nested Branching, in which there is some branching conditions involving more than one condition. For example, to determine the predicate value, calculate the discount of sale, calculate the interest in the bank that seen from some kind of balance amount of the input conditions .

5) Module 5 : Concept of Arrays $1 \mathrm{D}$ and 2D, where students can differentiate which variable array and ordinary variable. In addition, at the end of the module there is also a matter of practice, for example by discount of selling goods where the goods codes is a variable array

\section{DESIGN AND BUILT THE APPLICATION}

\subsection{Design and manufacture of CAL application}

Design and manufacture of CAL application is divided into two stages, namely: (1) design and built CAL applications to improve student learning outcomes in the course of logic algorithms, (2) perform testing / trials testing and implementation of the CAL application. Can be seen in Figure 1, the chart of distribution modules on the application of CAL for logic algorithm course. 
The International Journal of Multimedia \& Its Applications (IJMA) Vol.5, No.6, December 2013

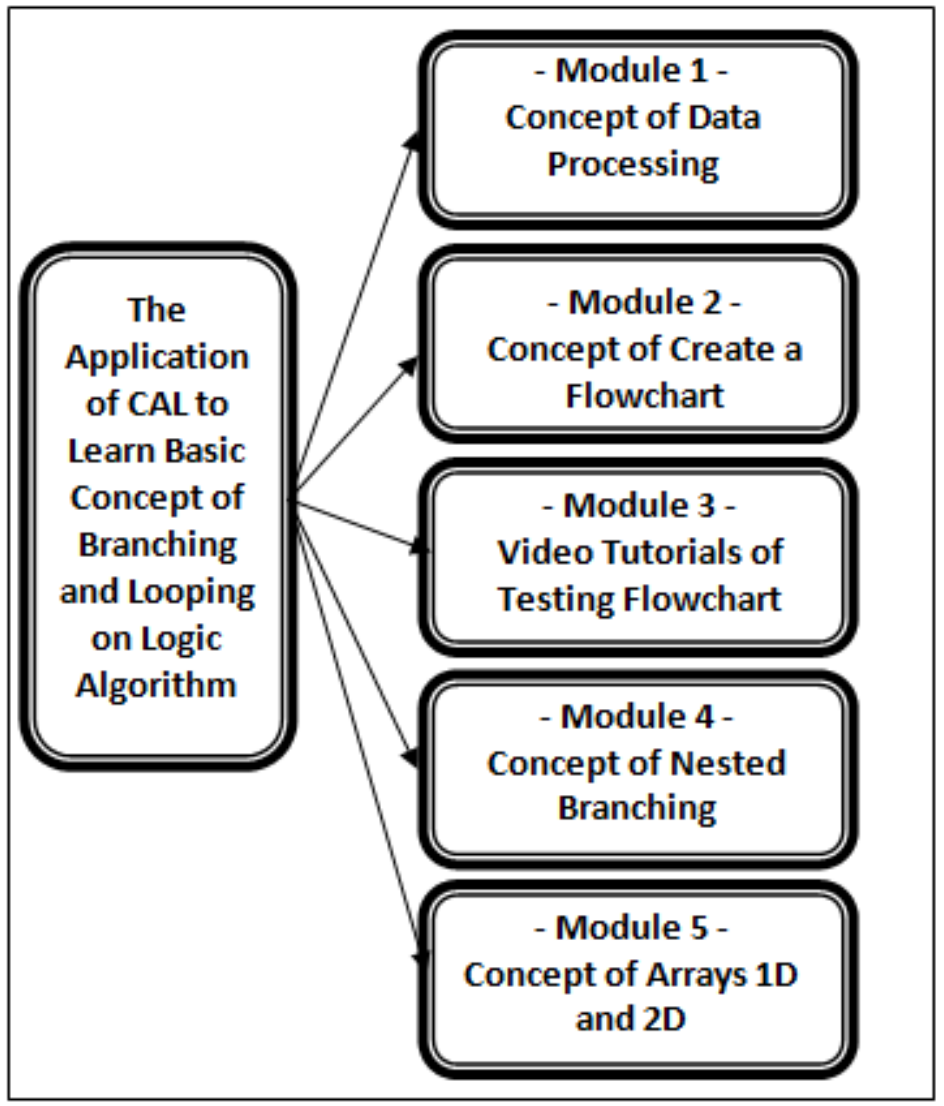

Figure 1. The chart of distribution modules on the application CAL for logic algorithm course

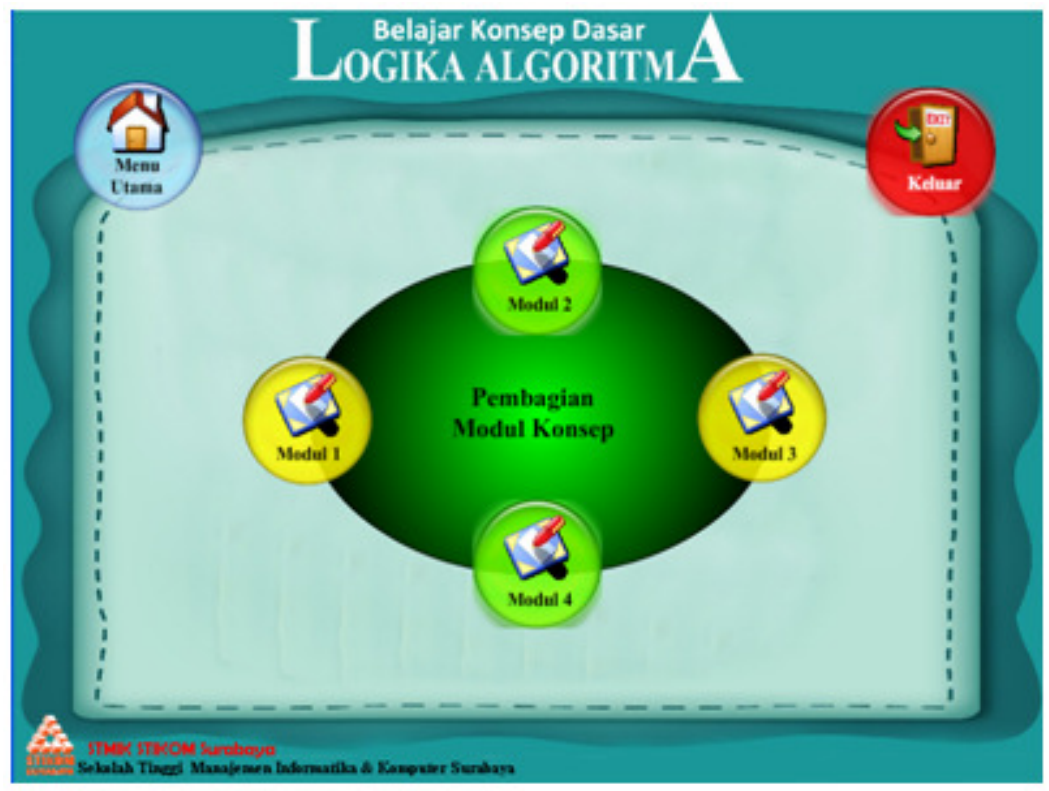

Figure 2. Main Application Form designing CAL Logic Algorithm. 
The International Journal of Multimedia \& Its Applications (IJMA) Vol.5, No.6, December 2013

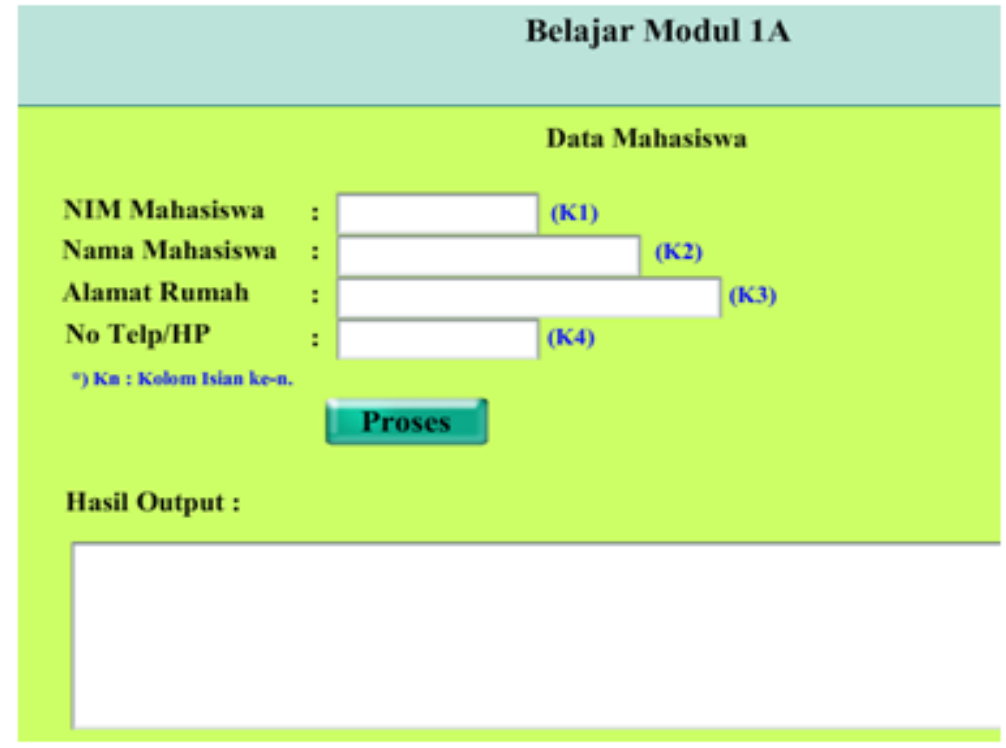

Figure 3. Design Form Sub-Module 1A - Student Data Processing

In Figure 3 can be seen that the user must input the amount of data in the form provided. Data must be entered in sequence, so that the sub module 1A, users are introduced to the definition or meaning of Sequential Processes. While the introduction of the branching process introduced in sub module $1 \mathrm{~B}$ and iteration process introduced in sub modules $1 \mathrm{C}$. The design of module 2 is divided into 3 sub modules as well, sub module $2 \mathrm{~A}$, sub module $2 \mathrm{~B}$, and sub module $2 \mathrm{C}$. The design of module 2 can be seen in Figure 4.

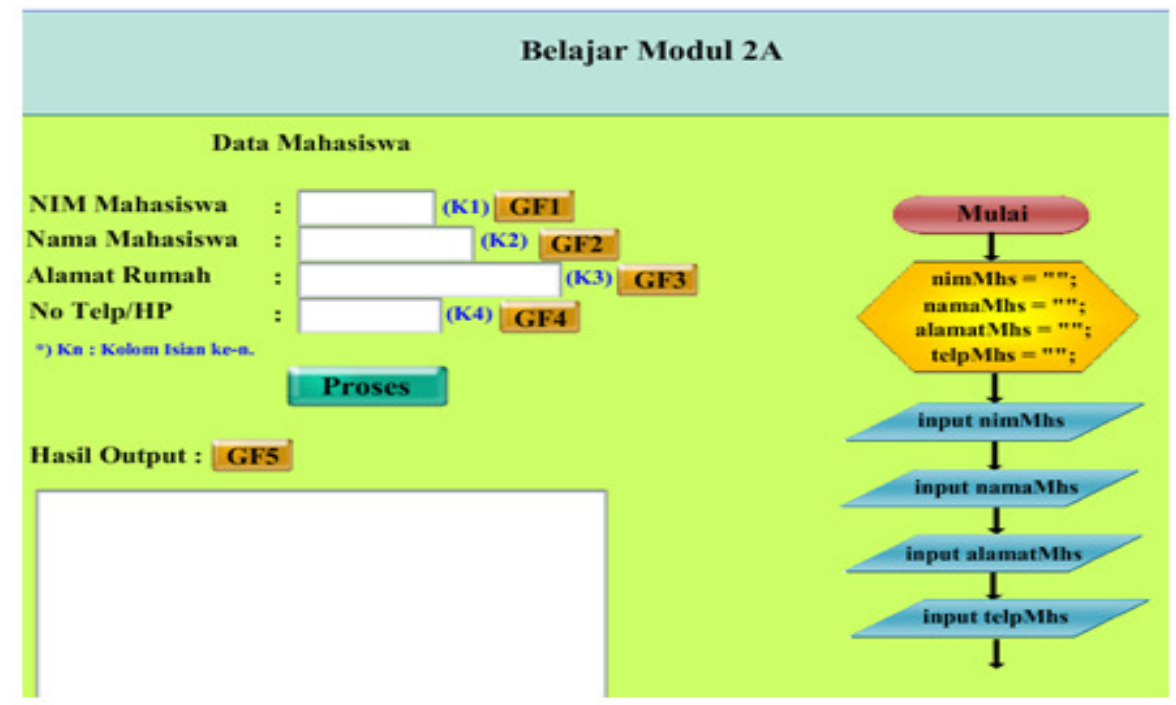

Figure 4. Design Form of sub module 2 - Concept of Create a Flowchart

Module 3 contains video tutorials using Raptor. Raptor is an application to test whether the flowchart that was made to run well or not. Video tutorial was created using Camtasia Studio. The tutorial video display can be seen in Figure 5. 
The International Journal of Multimedia \& Its Applications (IJMA) Vol.5, No.6, December 2013

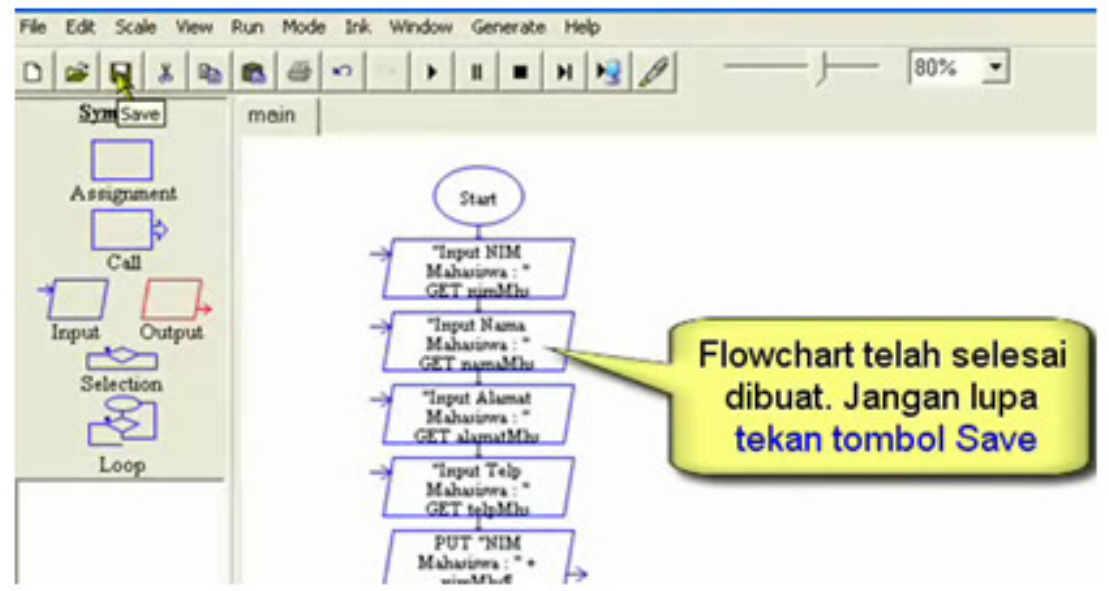

Figure 5. Design Form of Module 3 - Video Tutorial Testing the Flowchart Using RAPTOR Application.

Module 4 contains the concept of Nested Branching. When selecting Sub Module 4A, users are required to fill textfield for NIM, Name, Subject, and Final Score. Nested Branching Concept is used to determine the Final Value. The display module 4 can be seen in Figure 6. If the input of final value is greater than 90 , then it will be processed with printed the predicate is Very Good / Excellent. The condition was made with the following rules:
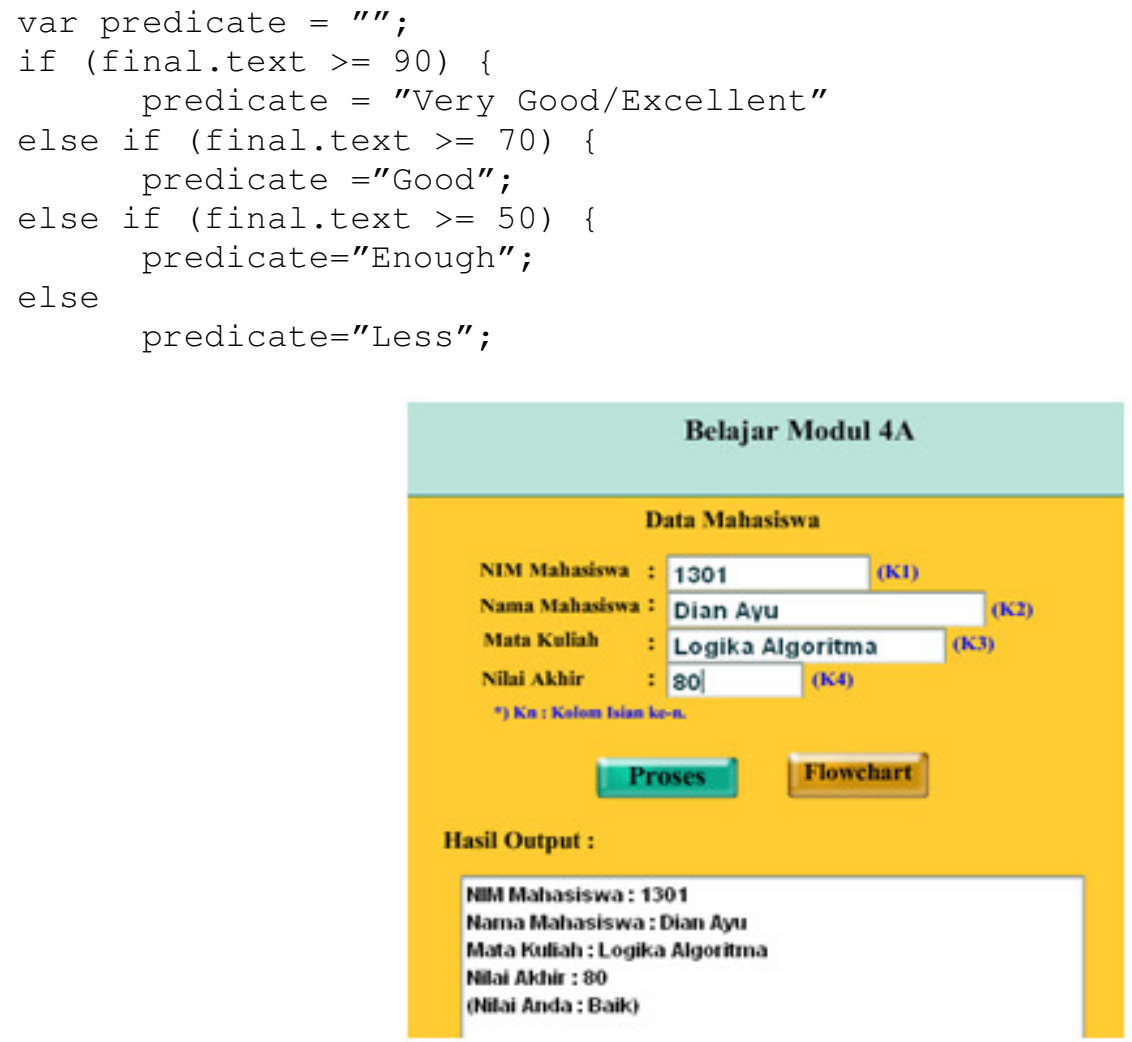

Figure 6. Design Form Module 4 - Concept of Nested Branching 
The International Journal of Multimedia \& Its Applications (IJMA) Vol.5, No.6, December 2013

Module 5 contains 2 sub modules. Sub Module 5A contains form filling data using array 1D and 2D variable. From entry data process, students can press a button of Array 1D to display the instructions which is a variable which is an array and ordinary variable. While the sub 5B module contains exercises, both only use array 1D variable or use of array 2D variable. Examples of exercises that only use array 1D is sales discount, where the item code is array 1D of variables that can be chosen by the user. Discounts on the sale, still continue to use the concept of nested branching on module 4. The design of module 5 can be seen in Figure 7.

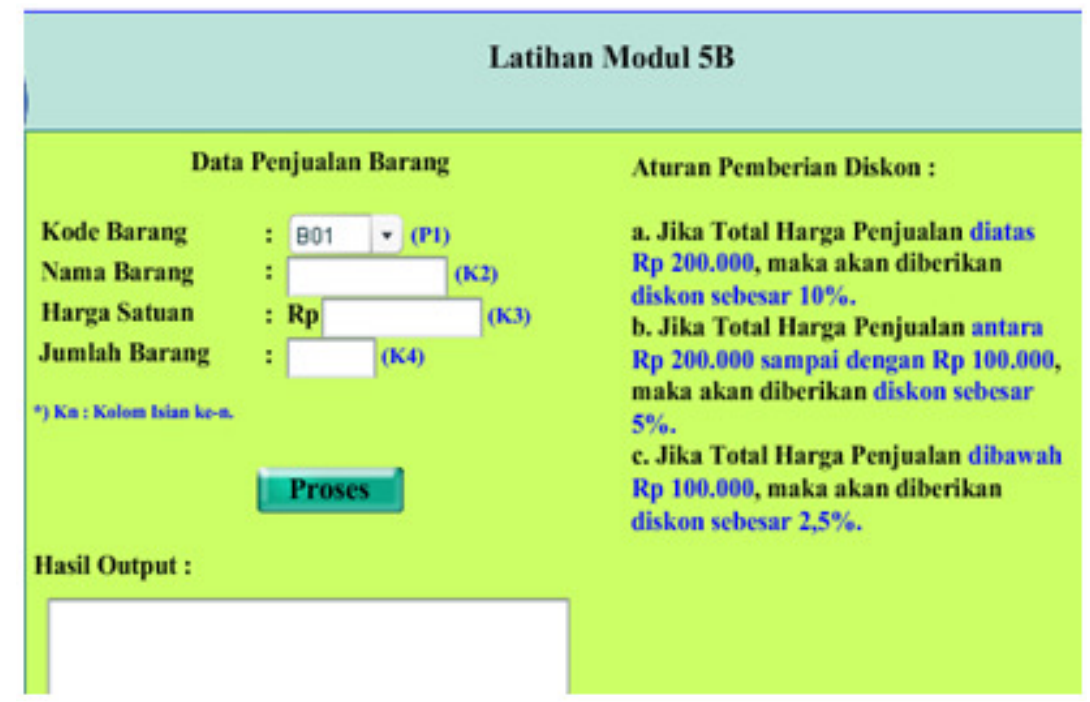

Figure 7. Design of Module 5B. Exercise Using Concept Arrays 1D and 2D.

\subsection{Research Activities with Modules and Analysis}

Testing and Implementation phases, including testing multimedia software applications are made. Testing and implementation is done by:

1. Testing conducted on 2 groups of students, where the first group is a small group (10 people) and the second group is a large group (30 people). Both groups were taught using the same application of CAL Logic Algorithm.

2. Examine the differences between the learning outcomes of students in small groups and large groups.

Students who made the pilot object is student of STMIK STIKOM Surabaya who generation in 2013 (new students), and has never taken a logic algorithm course in the previous study. The presentation in course of logic algorithms using CAL application is done in 5 meeting. At each end of the meeting, will be given a written test to measure the success of the students to understand the material in each module. The Test Results of all modules for Small classes (10 students) can be seen in Table 1. While the result of Test Module 1,2,3,4,5 for Large Classes (30 students) can be seen in Table 2. The fundamental difference in values is better for groups Large Class (30 students). 
The International Journal of Multimedia \& Its Applications (IJMA) Vol.5, No.6, December 2013

Table 1. The Test Results for Small Classes (10 students)

\begin{tabular}{|c|c|c|c|c|c|}
\hline Value/Module & M1 & M2 & M3 & M2 & M3 \\
\hline $\mathbf{8 0 - 1 0 0}(\mathbf{A})$ & 7 & 6 & 6 & 6 & 5 \\
\hline $\mathbf{7 5 - 7 9}(\mathbf{B}+)$ & 0 & 0 & 2 & 0 & 2 \\
\hline $\mathbf{6 5 - 7 4}(\mathbf{B})$ & 2 & 4 & 2 & 4 & 3 \\
\hline $\mathbf{6 0 - 6 4}(\mathbf{C}+)$ & 1 & 0 & 0 & 0 & 0 \\
\hline $\mathbf{5 5}-\mathbf{5 9}(\mathbf{C})$ & 0 & 0 & 0 & 0 & 0 \\
\hline $\mathbf{4 0 - 5 4}(\mathbf{D})$ & 0 & 0 & 0 & 0 & 0 \\
\hline $\mathbf{0 - 3 9}(\mathbf{E})$ & 0 & 0 & 0 & 0 & 0 \\
\hline $\begin{array}{c}\text { SUM of } \\
\text { Student }\end{array}$ & $\mathbf{1 0}$ & $\mathbf{1 0}$ & $\mathbf{1 0}$ & $\mathbf{1 0}$ & $\mathbf{1 0}$ \\
\hline
\end{tabular}

Table 2. The Test Results for Large Classes (10 students)

\begin{tabular}{|c|c|c|c|c|c|}
\hline Value/Module & M1 & M2 & M3 & M4 & M5 \\
\hline $\mathbf{8 0 - 1 0 0 ~ ( A ) ~}$ & 26 & 22 & 20 & 22 & 19 \\
\hline $\mathbf{7 5 - 7 9}(\mathbf{B}+)$ & 2 & 6 & 7 & 6 & 6 \\
\hline $\mathbf{6 5}-\mathbf{7 4}(\mathbf{B})$ & 2 & 2 & 3 & 2 & 5 \\
\hline $\mathbf{6 0 - 6 4}(\mathbf{C}+)$ & 0 & 0 & 0 & 0 & 0 \\
\hline $\mathbf{5 5}-\mathbf{5 9}(\mathbf{C})$ & 0 & 0 & 0 & 0 & 0 \\
\hline $\mathbf{4 0 - 5 4}(\mathbf{D})$ & 0 & 0 & 0 & 0 & 0 \\
\hline $\mathbf{0 - 3 9}(\mathbf{E})$ & 0 & 0 & 0 & 0 & 0 \\
\hline $\begin{array}{c}\text { SUM of } \\
\text { Student }\end{array}$ & $\mathbf{3 0}$ & $\mathbf{3 0}$ & $\mathbf{3 0}$ & $\mathbf{3 0}$ & $\mathbf{3 0}$ \\
\hline
\end{tabular}

Based on the results of testing the application of CAL for Logic Algorithms course, either a small class of test results (Table 1) as well as a large class of test results (Table 2), it can be seen that most of the students are in the range of values 80-100 (A). Although taught more than 5 meetings, but students were able to show the best results. It is aimed at achieving competence Logic Algorithms courses. This suggests that the presence of CAL application modules, can assist students in working on the problems of logic algorithms easily. So that students can obtain the maximum results in the logic of the algorithm course.

\section{CONCLUSION}

The conclusion that can be drawn from this study are (1) After going through the stages of the trial, the majority of students can understand the basic concepts of logic algorithms well. This is evidenced by student learning outcomes that are in the range of 80-100. (2) Application of CAL Logic Algorithm can be used as a tool or medium of instruction, both in the formal classroom, as well as students at home. And the last conclusion is (3) Application of CAL Logic Algorithm can help improve learning outcomes of students new to the field of computer programming. This is 
The International Journal of Multimedia \& Its Applications (IJMA) Vol.5, No.6, December 2013

due to the interactive nature of the user application, so it requires students to be actively involved in it.

\section{FURTHER RESEARCH}

Based on the results of this study, it can be given a few suggestions that can be used for further research are delivery module is not enough just meeting held on module 5, because in real conditions it took several meetings to gain additional student competence as expected. The test results of modules that demonstrate the value of good, is likely to come from the individual factors, such as patterns of thinking good logic, the logic of the algorithm to get the material experience while pa high school / vocational school. For the last suggestion, initial test should be performed as an information equalization ability to think every student.

\section{REFERENCES}

[1] Ardianto, A., Mayadewi, P., Frestiyanto, R. (2011). Aplikasi Pembelajaran Algoritma Dan Pemrograman Berbasis Web. Skripsi. Bandung : Poltek.

[2] Farrell,J. (2011). Programming Logic and Design Introductory, Sixth Edition. Canada: Course Technology.

[3] García, RR. (2007). Interactive Multimedia Animation With Macromedia Flash In Descriptive Geometry Teaching. Computers \& Education, Volume 49, Issue 3, 615-639.

[4] Kinzie, M. B. \& Joseph, D. R. D. (2008). Game Activity Preferences of Middle School Children: Implications for Educational Game Design. Educational Technology Research \& Development (56) 5-6, 643-663.

[5] Milovanović, M., Obradović, J.M., Milajić, A. (2013). Application Of Interactive Multimedia Tools In Teaching Mathematics - Examples Of Lessons From Geometry. The Turkish Online Journal of Educational Technology, volume (12) Issue 1, 19-31.

[6] Neo, M., Neo , K.T., Tan , H. Y. (2012). Applying Authentic Learning Strategies In A Multimedia And Web Learning Environment (Mwle): Malaysian Students' Perspective. The Turkish Online Journal Of Educational Technology, Volume 11 Issue 3, 50-60.

[7] Prasetyawan, G., Barakbah, A.R., Munif, A. (2007). Pembuatan Perangkat Lunak Alat Bantu Logika dan Algoritma. Skripsi. Malang : Joint Program D4 BA.

[8] Sembiring, Y.Y. (2009). Algoritma Dan Implementasi Alat Bantu Pemecahan Masalah Matematika. Skripsi, tidak diterbitkan. Medan : Universitas Sumatra Utara.

[9] Sfenrianto,. (2009). A Model of Adaptive E-Learning System Based on Student's Motivation. Proceedings from ICCIT-09: International Conference on Creative Communication and Innovative Technology, 2009. Tangerang: CCIT Journal.

[10] Shamir, Budookhan., Santally, Mohammad Issack. (2010). Investigating a Multimedia Approach To Minimize Problems Encountered By Students in "algorithm design and programming concepts". Proceeding The 3rd Annual Forum on e-Learning Excellence, ISBN 978-9948-15-396-2.

[11] Shariffudin, S.R., Azanan, S., and Hsien, G.J. (2012). Multiple Intelligence Multimedia Courseware (Mimco) Based On The Constructivist-Contextual Model For The Learning Of Some Chemistry Concepts. International Journal of Future Computer and Communication, Vol. 1, No. 1, 29-31.

[12] Sutopo, H. (2011). Selection Sorting Algorithm Visualization Using Flash. The International Journal of Multimedia \& Its Applications (IJMA). Vol.3, No.1, page 22-35. 
The International Journal of Multimedia \& Its Applications (IJMA) Vol.5, No.6, December 2013

\section{AUTHORS}

Endra Rahmawati was born in Surabaya, Indonesia on October 12, 1987. She is Magister of Computer in Information Technology of Institute of Applied Science and Technology Surabaya, Indonesia, graduated in November 2012. In 2009, she graduated from the University August 17, 1945 Surabaya, Indonesia, majoring in Informatics Engineering. Endra is currently a lecturer of Information System at The Higher School of Informatic Management \& Computer Engineering (STMIK STIKOM Surabaya), Indonesia since 2012.

Sulis Janu Hartati was born on January 22, 1964, in Kediri, Indonesia. In 2012, she has completed her Doctorate in Mathematics Education at University of Surabaya, Indonesia. She has completed her magister in informatics from Institute of Technology Sepuluh November Surabaya, Indonesia in 1998. In 1987, she has got her bachelor from University of Airlangga Surabaya, Indonesia and taking Mathematics as her major. She has been working as a lecturer in Information System Department at STMIK STIKOM Surabaya, Indonesia since 1988.
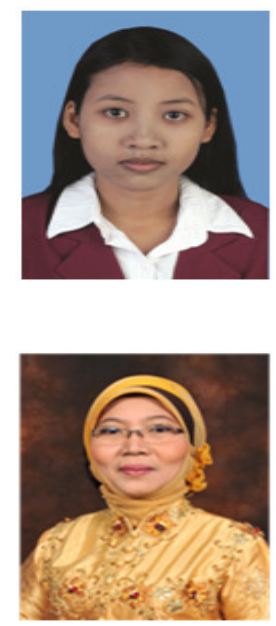